\title{
Artificial Erythrina Alkaloids from Three Erythrina Plants, E. variegata, E. crista-galli and E. arborescens
}

\author{
Bing-Jie Zhang ${ }^{1,2} \cdot$ Jing $\mathrm{Wu}^{1} \cdot$ Mei-Fen Bao ${ }^{1,2} \cdot$ Fang Wang $^{1,3} \cdot$ Xiang-Hai Cai ${ }^{1,3}$
}

Received: 7 January 2020 / Accepted: 19 February 2020 / Published online: 4 March 2020

(c) The Author(s) 2020

\begin{abstract}
Fourteen unprecedented artificial Erythrina alkaloids were isolated from the Erythrina variegata, E. crista-galli and E. arborescens (Fabaceae). The structures of these alkaloids were determined by spectroscopic analyses. Their possible formations were proposed. All isolated compounds showed no cytotoxicity and hypoglycemic activity at cell screening bioassay.
\end{abstract}

Keywords Fabaceae $\cdot$ Erythrina variegata $\cdot$ E. crista-galli $\cdot$ E. arborescens $\cdot$ Artificial products $\cdot$ Erythrina alkaloids

\section{Introduction}

The Erythrina-type alkaloids with 6/5/6/6 spirocycle systems and stable $5 S$-chiral center are derived from two tyrosine units via oxidative coupling and intramolecular rearrangement. Since the first phytochemical research on Erythrina alkaloid in 1930s [1], the total number now stands at well over 110 alkaloids reported from plants of Erythrina genus [2]. Bioassay screening of these alkaloids showed anxiolytic-like actitivity [3], induced sleep [4], anticonvulsant actitivity [5], neuronal nicotinic acetylcholine receptor antagonism [6], leishmanicidal [7], anticataract [7], and antifeedant activity [8]. Our previous research disclosed natural dimeric [9, 10] and trimeric [11] Erythrina alkaloids, alkaloidal glucosides [10], and complex monomers [12-14]. However, during the extraction and separation of Erythrina alkaloids, some artificial products would be

Bing-Jie Zhang and Jing Wu have contributed equally to this work.

Dedicated to Professor Han-Dong Sun on the occasion of his 80th birthday.

Xiang-Hai Cai

xhcai@mail.kib.ac.cn

1 State Key Laboratory of Phytochemistry and Plant Resources in West China, Kunming Institute of Botany, Chinese Academy of Sciences, Kunming 650201, China

2 University of Chinese Academy of Sciences, Beijing 100049, China

3 Yunnan Key Laboratory of Natural Medicinal Chemistry, Kunming 650201, China produced. Consideration of the NMR spectra characteristics and potential activities of Erythrina alkaloid, we here systematically summarized these artifacts from E. arborescens, E. crista-galli and E. variegata (Fig. 1). Their cytotoxicity against three cancer cells and hypoglycemic activity on 3T3L1 myoblasts cell were screened. This paper will describe their isolation, structure determination and possible mechanism of formation.

\section{Results and Discussion}

Alkaloid 1 was obtained as white amorphous powder. Its IR absorption bands at 3441, 1640,1503, $1480 \mathrm{~cm}^{-1}$ indicated the presence of the hydroxyls and aromatic rings. Moreover, the UV absorptions at 204, 239 and $290 \mathrm{~nm}$ indicated a tetrahydroisoquinoline chromophore [15]. These spectra were consistent with the characteristics of an Erythrina alkaloid. Alkaloid $\mathbf{1}$ had a molecular formula $\mathrm{C}_{39} \mathrm{H}_{40} \mathrm{~N}_{2} \mathrm{O}_{9}$ as established by the HRESIMS $\mathrm{m} / \mathrm{z}$ at $681.2811[\mathrm{M}+\mathrm{H}]^{+}$, together with the ${ }^{1} \mathrm{H}$ and ${ }^{13} \mathrm{C}$ NMR spectroscopic data. In the ${ }^{1} \mathrm{H}$ NMR spectrum of $\mathbf{1}$ (Table 1), four aromatic singlet proton $\left(\delta_{\mathrm{H}} 7.08,7.01,6.74 \times 2\right)$, two pairs of olefin $\left[\delta_{\mathrm{H}} 7.16\right.$ $(d d, J=10.2,4.2 \mathrm{~Hz}), 5.92(d, J=10.2 \mathrm{~Hz})$, and $6.56(d d$, $J=10.2,2.4 \mathrm{~Hz}), 6.06(d, J=10.2 \mathrm{~Hz})]$, two methylenedioxy group $\left(\delta_{\mathrm{H}} 5.96,5.94,5.93\right.$ and 5.92), and two methoxyl group $\left(\delta_{\mathrm{H}} 3.29\right.$ and 3.24) signals indicated that 1 might be an Erythrina alkaloid dimer. In comparison with the reported dimer, erythrivarine A [9], alkaloid 1 had three more signals at $\delta_{\mathrm{C}} 208.1,47.5$ and 31.2 in the ${ }^{13} \mathrm{C}$ NMR spectra and 56 mass units higher in molecular weight, which showed 


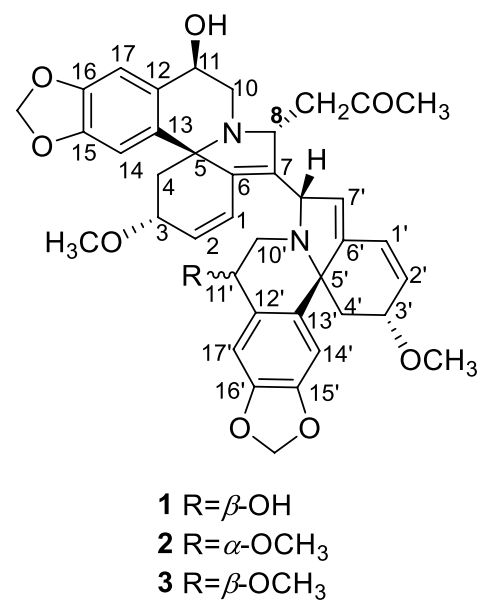

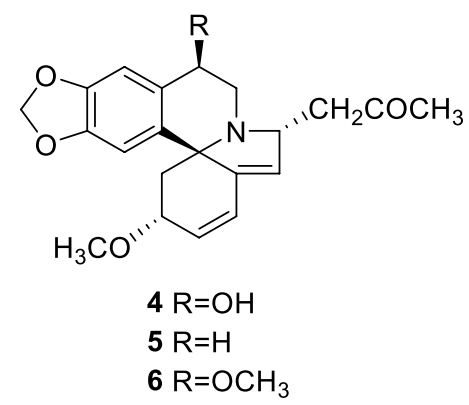

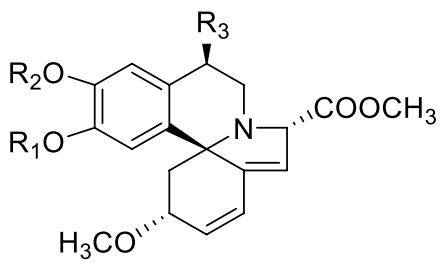

$$
\begin{aligned}
& 7 \mathrm{R}_{1}=\mathrm{R}_{2}=\mathrm{CH}_{3} \mathrm{R}_{3}=\mathrm{H} \\
& 8 \mathrm{R}_{1}-\mathrm{CH}_{2}-\mathrm{R}_{2} \mathrm{R}_{3}=\mathrm{OH}
\end{aligned}
$$<smiles>[R20]Oc1cc2c(cc1O[R20])[C@]13C[C@H](OC)C=CC1=C[C@H](CCOC(=O)OC)N3C[C@@H]2[R3]</smiles><smiles></smiles>

$9 \mathrm{R}_{1}-\mathrm{CH}_{2}-\mathrm{R}_{2} \mathrm{R}_{3}=\mathrm{H}$

$10 \mathrm{R}_{1}-\mathrm{CH}_{2}-\mathrm{R}_{2} \mathrm{R}_{3}=\mathrm{OH}$

$11 \mathrm{R}_{1}-\mathrm{CH}_{2}-\mathrm{R}_{2} \mathrm{R}_{3}=\mathrm{OCH}_{3}$

$12 \mathrm{R}_{1}=\mathrm{R}_{2}=\mathrm{CH}_{3} \mathrm{R}_{3}=\mathrm{H}$

Fig. 1 Chemical structures of 14 artificial Erythrina alkaloids

an extra 2-oxopropyl group in 1. In the HMBC spectrum, correlations of $\delta_{\mathrm{H}} 4.20(\mathrm{H}-8)$ with $\delta_{\mathrm{C}} 53.9(\mathrm{C}-10), \delta_{\mathrm{C}} 136.2$ $(\mathrm{C}-7)$ and $\delta_{\mathrm{C}} 208.1(\mathrm{C}=\mathrm{O})$ indicated the 2-oxopropyl group at C-8. Further analysis of the 2D NMR revealed that the other parts of compound 1 were consistent with those of erythrivarine A.

Alkaloids $\mathbf{2}$ and $\mathbf{3}$ showed the same molecular formula $\mathrm{C}_{40} \mathrm{H}_{42} \mathrm{~N}_{2} \mathrm{O}_{9}$ as established by HRESIMS $(\mathrm{m} / \mathrm{z}, 695.2968$ $[\mathrm{M}+\mathrm{H}]^{+}$in 2; $\mathrm{m} / z 695.2970[\mathrm{M}+\mathrm{H}]^{+}$in 3). In the ${ }^{1} \mathrm{H}$ and ${ }^{13} \mathrm{C}$ NMR spectra, the chemical shifts of $\mathbf{2}$ and $\mathbf{3}$ showed good agreement with those of 1 , except those signals around the $\mathrm{C}-11^{\prime}$ position $\left(\mathrm{C}-10^{\prime} / 11^{\prime} / 12^{\prime}\right)$. The $\mathrm{C}-11^{\prime}$ carbon of $\mathbf{1}$ was resonated at $\delta 64.9$, however, signals of the same carbon were observed at $\delta 74.7$ and $\delta 74.5$ in $\mathbf{2}$ and $\mathbf{3}$, respectively. In addition, an extra methoxyl group $\left(\delta_{\mathrm{H}} 3.54\right.$ in $2, \delta_{\mathrm{H}} 3.36$ in $\mathbf{3}$ ) was observed, which indicated that both $\mathbf{2}$ and $\mathbf{3}$ had a methoxyl group at the $\mathrm{C}-11^{\prime}$ position instead of a hydroxyl group in 1. Chemical shifts of H-10', H-11' and H-17' protons (Table 1) of $\mathbf{2}$ and $\mathbf{3}$ implied the configuration of 11'$\mathrm{OCH}_{3}$ in $\mathbf{2}$ and $\mathbf{3}$ were different. In the ROESY spectrum, the NOE correlation of $\mathrm{H}-3^{\prime} \beta / \mathrm{H}-4^{\prime} \beta$ and $\mathrm{H}-11^{\prime} / \mathrm{H}-4^{\prime} \alpha$ in 3 suggested its $11^{\prime}-\mathrm{OCH}_{3}$ was in $\beta$-orientation. The NOE correlation of $\mathrm{H}-11^{\prime} / \mathrm{H}-4^{\prime} \beta$ in 2 suggested its $11^{\prime}-\mathrm{OCH}_{3}$ was in $\alpha$-orientation.

The HRESIMS of 4 showed the pseudomolecular ion at $m / z 370.1651[\mathrm{M}+\mathrm{H}]^{+}$(calc. for $\mathrm{C}_{21} \mathrm{H}_{23} \mathrm{NO}_{5}, 370.1652$ ). The ${ }^{13} \mathrm{C}$ NMR spectrum of 4 showed a methine at $64.7 \mathrm{ppm}$, which indicated the existence of hydroxy substituent. The
HMBC correlation between $\delta_{\mathrm{H}} 7.05(\mathrm{H}-17)$ with $\delta_{\mathrm{C}} 64.7$ suggested the hydroxy at $\mathrm{C}-11$. Through detailed comparison of the 1D and 2D NMR spectrum, 4 was basically the same as erythranine [16] except for the 2-oxopropyl substituent $\left(\delta_{\mathrm{C}} 207.9,47.8\right.$ and 30.8). The HMBC spectrum showed correlations from $\delta_{\mathrm{H}} 3.98(\mathrm{H}-8)$ to $\delta_{\mathrm{C}} 52.6(\mathrm{C}-10)$, $\delta_{\mathrm{C}} 127.6(\mathrm{C}-7)$ and $\delta_{\mathrm{C}} 207.9(\mathrm{C}=\mathrm{O})$ disclosed 4 to be 8-(2-oxopropyl)-erythranine.

Alkaloid 5 displayed a hydrogen adduct ion at $\mathrm{m} / \mathrm{z}$ 354.1709 $[\mathrm{M}+\mathrm{H}]^{+}$(calc. for $\mathrm{C}_{21} \mathrm{H}_{23} \mathrm{NO}_{4}, 354.1707$ ). The 1D NMR spectroscopic data of compound 5 were similar to those of $\mathbf{4}$ except for the following differentiations: in the ${ }^{1} \mathrm{H}$ NMR spectrum, the signal displayed at $\delta_{\mathrm{H}} 4.72$ in $\mathbf{4}$ which was assigned to the active hydrogen in the hydroxy was disappeared in compound $\mathbf{5}$. Correspondingly, the methine signal at $\delta_{\mathrm{C}} 64.7(\mathrm{C}-11)$ in compound 4 was replaced with a methylene $\left(\delta_{\mathrm{C}} 26.0\right)$ in $\mathbf{5}$. Thus, compound $\mathbf{5}$ was an analogue of $\mathbf{4}$ without the hydroxy moiety and determined to be 8-(2-oxopropyl)-erythraline.

The HRESIMS of $\mathbf{6}$ gave a hydrogen adduct ion at $\mathrm{m} / \mathrm{z}$ $384.1806[\mathrm{M}+\mathrm{H}]^{+}$, indicative of a molecular formula of $\mathrm{C}_{22} \mathrm{H}_{25} \mathrm{NO}_{5}$. In comparing with those of 4 , the ${ }^{1} \mathrm{H}$ NMR spectrum of $\mathbf{6}$ gave signal of an addional methyoxyl group $\left(\delta_{\mathrm{H}} 3.55, \mathrm{~s}, 3 \mathrm{H}\right)$, and its ${ }^{13} \mathrm{C}$ NMR spectrum showed an downfield chemical shift $\delta_{\mathrm{C}} 74.8$. These findings suggested the C-11 of 6 was substituted by a methoxy rather than a hydroxy. Thus, the structure of $\mathbf{6}$ was determined to be 8-(2-oxopropyl))-11-methoxy-erythraline. 
Table $1{ }^{1} \mathrm{H}$ and ${ }^{13} \mathrm{C}$ NMR spectroscopic data for 1-3 in acetone- $d_{6}(\delta$ in ppm and $J$ in $\mathrm{Hz})$

\begin{tabular}{|c|c|c|c|c|c|c|}
\hline \multirow[t]{2}{*}{ Enrty } & \multicolumn{2}{|l|}{1} & \multicolumn{2}{|l|}{2} & \multicolumn{2}{|l|}{3} \\
\hline & $\delta_{\mathrm{H}}$ & $\delta_{\mathrm{C}}$ & $\delta_{\mathrm{H}}$ & $\delta_{\mathrm{C}}$ & $\delta_{\mathrm{H}}$ & $\delta_{\mathrm{C}}$ \\
\hline 1 & $7.16, \mathrm{dd}(10.2,4.2)$ & $124.6 \mathrm{~d}$ & $7.16, \mathrm{~d}(10.2)$ & $124.8 \mathrm{~d}$ & 7.06, overlap & $124.7 \mathrm{~d}$ \\
\hline 2 & $5.92, \mathrm{~d}(10.2)$ & $132.1 \mathrm{~d}$ & $6.00, \mathrm{~d}(10.2)$ & $132.2 \mathrm{~d}$ & $6.00, \mathrm{~d}(10.2)$ & $132.2 \mathrm{~d}$ \\
\hline 3 & $3.68, \mathrm{~m}$ & $76.9 \mathrm{~d}$ & $3.73, \mathrm{~m}$ & $76.8 \mathrm{~d}$ & $3.73, \mathrm{~m}$ & $77.0 \mathrm{~d}$ \\
\hline 4 & $\begin{array}{l}2.38, \mathrm{dd}(11.4,6.0) \\
1.68, \mathrm{t}(11.4)\end{array}$ & $43.6 \mathrm{t}$ & $\begin{array}{l}2.44, \mathrm{dd}(10.8,6.0) \\
1.69, \mathrm{t}(10.8)\end{array}$ & $42.9 \mathrm{t}$ & $\begin{array}{l}2.40, \mathrm{dd}(10.8,6.0) \\
1.70, \mathrm{t}(10.8)\end{array}$ & $43.0 \mathrm{t}$ \\
\hline 5 & & $69.2 \mathrm{~s}$ & & $68.9 \mathrm{~s}$ & & $69.2 \mathrm{~s}$ \\
\hline 6 & & $139.6 \mathrm{~s}$ & & $139.7 \mathrm{~s}$ & & $138.2 \mathrm{~s}$ \\
\hline 7 & & $136.2 \mathrm{~d}$ & & $136.8 \mathrm{~d}$ & & $135.6 \mathrm{~d}$ \\
\hline 8 & $4.20, \mathrm{~m}$ & $69.7 \mathrm{~d}$ & $4.30, \mathrm{~m}$ & $68.3 \mathrm{~d}$ & 4.23 , br s & $69.2 \mathrm{~d}$ \\
\hline 10 & $\begin{array}{l}3.48, \text { dd }(11.4,5.4) \\
2.51, \text { overlap }\end{array}$ & $53.9 \mathrm{t}$ & $\begin{array}{l}3.34, \text { dd }(11.4,4.8) \\
2.77, \text { br d }(11.4)\end{array}$ & $50.7 \mathrm{t}$ & $\begin{array}{l}3.47, \text { dd }(11.4,4.8) \\
2.61, \text { overlap }\end{array}$ & $53.2 \mathrm{t}$ \\
\hline 11 & $4.65, \mathrm{~m}$ & $64.7 \mathrm{~d}$ & $4.66, \mathrm{~m}$ & $64.7 \mathrm{~d}$ & $4.75, \mathrm{~m}$ & $64.8 \mathrm{~d}$ \\
\hline 12 & & $134.1 \mathrm{~s}$ & & $133.9 \mathrm{~s}$ & & $133.9 \mathrm{~s}$ \\
\hline 13 & & $132.2 \mathrm{~s}$ & & $132.6 \mathrm{~s}$ & & $132.6 \mathrm{~s}$ \\
\hline 14 & $6.74, \mathrm{~s}$ & $106.1 \mathrm{~d}$ & $6.73, \mathrm{~s}$ & $105.8 \mathrm{~d}$ & $6.90, \mathrm{~s}$ & $106.1 \mathrm{~d}$ \\
\hline 15 & & $147.7 \mathrm{~s}$ & & $147.3 \mathrm{~s}$ & & $147.3 \mathrm{~s}$ \\
\hline 16 & & $147.2 \mathrm{~s}$ & & $147.3 \mathrm{~s}$ & & $147.3 \mathrm{~s}$ \\
\hline 17 & $7.01, \mathrm{~s}$ & $108.7 \mathrm{~d}$ & 7.01, s & $108.6 \mathrm{~d}$ & $7.06, \mathrm{~s}$ & $107.3 \mathrm{~d}$ \\
\hline $\mathrm{OCH}_{2} \mathrm{O}$ & $\begin{array}{l}5.96, \mathrm{~s} \\
5.94, \mathrm{~s}\end{array}$ & $101.8 \mathrm{t}$ & $\begin{array}{l}5.96, \mathrm{~s} \\
5.95, \mathrm{~s}\end{array}$ & $101.8 \mathrm{t}$ & $\begin{array}{l}5.96, \mathrm{~s} \\
5.95, \mathrm{~s}\end{array}$ & $102.0 \mathrm{t}$ \\
\hline $\begin{array}{l}3-\mathrm{OCH}_{3} \\
11-\mathrm{OH}\end{array}$ & $3.29, \mathrm{~s}$ & $56.3 \mathrm{q}$ & $3.26, \mathrm{~s}$ & $56.2 \mathrm{q}$ & $\begin{array}{l}3.25, \mathrm{~s} \\
4.63, \mathrm{~d}(5.4)\end{array}$ & $56.2 \mathrm{q}$ \\
\hline $\mathrm{CH}_{2} \mathrm{COCH}_{3}$ & $\begin{array}{l}3.21, \text { overlap } \\
2.71, \mathrm{~m}\end{array}$ & $47.5 \mathrm{t}$ & $\begin{array}{l}3.42, \mathrm{~m} \\
2.71, \mathrm{~m}\end{array}$ & $47.1 \mathrm{t}$ & $\begin{array}{l}3.35, \mathrm{~m} \\
2.64, \mathrm{~m}\end{array}$ & $47.5 \mathrm{t}$ \\
\hline $\mathrm{CH}_{2} \mathrm{COCH}_{3}$ & & $208.1 \mathrm{~s}$ & & $207.8 \mathrm{~s}$ & & $208.2 \mathrm{~s}$ \\
\hline $\mathrm{CH}_{2} \mathrm{COCH}_{3}$ & $2.14, \mathrm{~s}$ & $31.2 \mathrm{q}$ & $2.13, \mathrm{~s}$ & $31.0 \mathrm{q}$ & $2.13, \mathrm{~s}$ & $31.2 \mathrm{q}$ \\
\hline $1^{\prime}$ & $6.56, \mathrm{dd}(10.2,2.4)$ & $125.5 \mathrm{~d}$ & $6.55, \mathrm{dd}(10.2,1.8)$ & $125.5 \mathrm{~d}$ & $6.54, \mathrm{dd}(10.2,1.8)$ & $125.7 \mathrm{~d}$ \\
\hline $2^{\prime}$ & $6.06, \mathrm{~d}(10.2)$ & $133.6 \mathrm{~d}$ & $6.06, \mathrm{~d}(10.2)$ & $133.6 \mathrm{~d}$ & $6.09, \mathrm{~d}(10.2)$ & $133.6 \mathrm{~d}$ \\
\hline $3^{\prime}$ & $3.32, \mathrm{~m}$ & $76.8 \mathrm{~d}$ & $3.93, \mathrm{~m}$ & $76.8 \mathrm{~d}$ & $4.06, \mathrm{~m}$ & $76.6 \mathrm{~d}$ \\
\hline $4^{\prime}$ & $\begin{array}{l}2.46, \mathrm{dd}(11.4,5.4) \\
1.79, \mathrm{t}(11.4)\end{array}$ & $41.6 \mathrm{t}$ & $\begin{array}{l}2.44, \mathrm{dd}(10.8,6.0) \\
1.79, \mathrm{t}(10.8)\end{array}$ & $41.6 \mathrm{t}$ & $\begin{array}{l}2.49, \mathrm{dd}(10.8,6.0) \\
1.77, \mathrm{t}(10.8)\end{array}$ & $40.9 \mathrm{t}$ \\
\hline $5^{\prime}$ & & $68.2 \mathrm{~s}$ & & $68.4 \mathrm{~s}$ & & $68.3 \mathrm{~s}$ \\
\hline $6^{\prime}$ & & $142.8 \mathrm{~s}$ & & $143.2 \mathrm{~s}$ & & $143.4 \mathrm{~s}$ \\
\hline $7^{\prime}$ & $5.58, \mathrm{~s}$ & $127.3 \mathrm{~d}$ & $5.57, \mathrm{~s}$ & $127.4 \mathrm{~d}$ & $5.58, \mathrm{~s}$ & $127.4 \mathrm{~d}$ \\
\hline $8^{\prime}$ & $4.92, \mathrm{~s}$ & $66.4 \mathrm{~d}$ & $4.90, \mathrm{~s}$ & $64.6 \mathrm{~d}$ & $4.92, \mathrm{~s}$ & $64.5 \mathrm{~d}$ \\
\hline $10^{\prime}$ & $\begin{array}{l}3.36 \text {, dd }(13.2,4.8) \\
2.83 \text {, overlap }\end{array}$ & $50.5 \mathrm{t}$ & $\begin{array}{l}3.42, \mathrm{dd}(13.2,4.0) \\
2.83, \mathrm{dd}(13.2,5.0)\end{array}$ & $47.0 \mathrm{t}$ & $\begin{array}{l}3.21, \mathrm{~m} \\
3.15, \mathrm{~m}\end{array}$ & $43.2 \mathrm{t}$ \\
\hline $11^{\prime}$ & $4.78, \mathrm{~m}$ & $64.9 \mathrm{~d}$ & $4.24, \mathrm{~s}$ & $74.7 \mathrm{~d}$ & $4.00, \mathrm{~s}$ & $74.5 \mathrm{~d}$ \\
\hline $12^{\prime}$ & & $132.5 \mathrm{~s}$ & & $129.2 \mathrm{~s}$ & & $129.2 \mathrm{~s}$ \\
\hline $13^{\prime}$ & & $133.4 \mathrm{~s}$ & & $132.6 \mathrm{~s}$ & & $132.6 \mathrm{~s}$ \\
\hline $14^{\prime}$ & $6.74, \mathrm{~s}$ & $105.9 \mathrm{~d}$ & $6.78, \mathrm{~s}$ & $106.0 \mathrm{t}$ & $6.75, \mathrm{~s}$ & $105.8 \mathrm{~d}$ \\
\hline $15^{\prime}$ & & $147.3 \mathrm{~s}$ & & $147.3 \mathrm{~s}$ & & $148.4 \mathrm{~s}$ \\
\hline $16^{\prime}$ & & $147.2 \mathrm{~s}$ & & $147.3 \mathrm{~s}$ & & $147.3 \mathrm{~s}$ \\
\hline $17^{\prime}$ & $7.08, \mathrm{~s}$ & $106.8 \mathrm{~d}$ & $6.92, \mathrm{~s}$ & $108.1 \mathrm{~d}$ & $7.37, \mathrm{~s}$ & $110.3 \mathrm{~d}$ \\
\hline $\mathrm{OC}^{\prime} \mathrm{H}_{2} \mathrm{O}$ & $\begin{array}{l}5.93, \mathrm{~s} \\
5.92, \mathrm{~s}\end{array}$ & $101.7 \mathrm{t}$ & $\begin{array}{l}5.95, \mathrm{~s} \\
5.94, \mathrm{~s}\end{array}$ & $101.8 \mathrm{t}$ & $\begin{array}{l}5.95, \mathrm{~s} \\
5.94, \mathrm{~s}\end{array}$ & $101.8 \mathrm{t}$ \\
\hline $\begin{array}{l}3^{\prime}-\mathrm{OCH}_{3} \\
11^{\prime}-\mathrm{OCH}_{3}\end{array}$ & $3.24, \mathrm{~s}$ & $56.2 \mathrm{q}$ & $\begin{array}{l}3.29, \mathrm{~s} \\
3.54, \mathrm{~s}\end{array}$ & $\begin{array}{l}56.2 \mathrm{q} \\
58.1 \mathrm{q}\end{array}$ & $\begin{array}{l}3.35, \mathrm{~s} \\
3.36, \mathrm{~s}\end{array}$ & $\begin{array}{l}56.3 \mathrm{q} \\
58.0 \mathrm{q}\end{array}$ \\
\hline
\end{tabular}

${ }^{1} \mathrm{H} N M R$ recorded at $600 \mathrm{MHz},{ }^{13} \mathrm{C} \mathrm{NMR}$ recorded at $150 \mathrm{MHz}$ 
The molecular formula of 7 was determined to be $\mathrm{C}_{21} \mathrm{H}_{25} \mathrm{NO}_{5}$ from the HRESIMS $m / z$ at $394.1626[\mathrm{M}+\mathrm{Na}]^{+}$. Its ${ }^{1} \mathrm{H}$ NMR spectrum showed two aromatic singlet protons $\left(\delta_{\mathrm{H}} 6.84\right.$ and 6.76$)$, three conjugate olefin signals $\left(\delta_{\mathrm{H}} 6.60\right.$, 6.10 and 5.67), and four methoxy groups $\left(\delta_{\mathrm{H}} 3.28,3.70,3.78\right.$ and 3.97). The ${ }^{13} \mathrm{C}$ NMR spectrum of 7 showed three methylenes $\left(\delta_{\mathrm{C}} 24.6,43.3,44.4\right)$, two methines $\left(\delta_{\mathrm{C}} 76.9\right.$ and 70.5$)$ and a carbonyl $\left(\delta_{\mathrm{C}} 172.1\right)$. These data suggested 7 might be a carbomethoxyl derivative of erysotrine [17]. The HMBC correlations from $\delta_{\mathrm{H}} 3.78\left(\mathrm{OCH}_{3}\right)$ and $\delta_{\mathrm{H}} 4.33(\mathrm{H}-8)$ to $\delta_{\mathrm{C}}$ $172.1(\mathrm{C}=\mathrm{O})$ assigned the carbomethoxy at $\mathrm{C}-8$. The molecular formula of 8 was determined to be $\mathrm{C}_{20} \mathrm{H}_{21} \mathrm{NO}_{6}$ from the HRESIMS $m / z$ at $372.1444[\mathrm{M}+\mathrm{H}]^{+}$. The ${ }^{1} \mathrm{H}$ and ${ }^{13} \mathrm{C}$ NMR the structural pattern of $\mathbf{8}$ was identical to that of $\mathbf{5}$, and the additional carbomethoxyl moiety was identical to that of $\mathbf{7}$. Accordingly, the structures of $\mathbf{7}$ and $\mathbf{8}$ were determined to be 8-carbomethoxyerysotrine and 8-carbomethoxyerythranine, respectively.

Alkaloid 9 showed molecular ion peaks at $\mathrm{m} / \mathrm{z} 370.1652$ $[\mathrm{M}+\mathrm{H}]^{+}$, suggesting the molecular formulae $\mathrm{C}_{21} \mathrm{H}_{24} \mathrm{NO}_{5}$. In comparing with compound $\mathbf{5}$, the ${ }^{1} \mathrm{H}$ and ${ }^{13} \mathrm{C}$ NMR signal of $\delta_{\mathrm{H}} 2.13\left(\mathrm{CH}_{3}\right)$ and $\delta_{\mathrm{C}} 207.7\left(\mathrm{CH}_{2} \mathrm{COCH}_{3}\right)$ in 5 were changed to $\delta_{\mathrm{H}} 3.61\left(\mathrm{OCH}_{3}\right)$ and $\delta_{\mathrm{C}} 172.5\left(\mathrm{CH}_{2} \mathrm{COOCH}_{3}\right)$ in 9, respectively. The remaining NMR data were almost identical to those of 5. Thus, the structure of $\mathbf{9}$ was determined to be 8-acetatemethoxyerythraline.

The molecular formulas of compounds $\mathbf{1 0}$ and $\mathbf{1 1}$ were deduced to be $\mathrm{C}_{21} \mathrm{H}_{23} \mathrm{NO}_{6}$ and $\mathrm{C}_{22} \mathrm{H}_{25} \mathrm{NO}_{6}$ from the HRESIMS at $m / z 386.1599[\mathrm{M}+\mathrm{H}]^{+}$and $400.1758[\mathrm{M}+\mathrm{H}]^{+}$, respectively. The ${ }^{1} \mathrm{H}$ and ${ }^{13} \mathrm{C} \mathrm{NMR}$ data of both $\mathbf{1 0}$ and 11 are very similar to those of $\mathbf{9}$ except that the methylene signal was replaced by an oxymethine signal at the $\mathrm{C}-11$ position. Further, in the ${ }^{13} \mathrm{C}$ NMR, the signal for $\mathrm{C}-11$ appeared at 64.8 and 74.7 ppm for compounds $\mathbf{1 0}$ and 11, similar to that of $\mathbf{4}$ and $\mathbf{6}$, respectively. Thus, $\mathbf{1 0}$ was identified as 8-acetatemethoxyerythranine. $\mathbf{1 1}$ had an extra methoxy and was identified as 8 -acetatemethoxy- $10 \beta$-methoxyerythraline.

The molecular formula 12 was established as $\mathrm{C}_{22} \mathrm{H}_{27} \mathrm{NO}_{5}$ based on the HRESIMS $m / z=386.1964[\mathrm{M}+\mathrm{H}]^{+}$. From the ${ }^{1} \mathrm{H}$ and ${ }^{13} \mathrm{C}$ NMR data, the structure of $\mathbf{1 2}$ was very similar to 9 except for the replacement of methylenedioxy group by two methoxys at C-15 and C-16. This was confirmed from the HMBC and HSQC spectra. Alkaloid 12 was thus identified as 8-acetatemethoxyerysotrine.

The HRESIMS $m / z$ at 394.1628 $[\mathrm{M}+\mathrm{Na}]^{+}$of $\mathbf{1 3}$ assigned the molecular formula to be $\mathrm{C}_{21} \mathrm{H}_{25} \mathrm{NO}_{5}$, 58 mass units higher than that of erysotrine. Its ${ }^{13} \mathrm{C}$ NMR spectrum gave an additional methylene $\left(\delta_{\mathrm{C}} 34.9\right)$ and a carbonyl $\left(\delta_{\mathrm{C}} 172.3\right)$ signals, indicating the existence of an acetyl group. The HMBC correlations from $\delta_{\mathrm{H}} 2.51\left(\mathrm{CH}_{2} \mathrm{CO}\right)$ and $\delta_{\mathrm{H}} 4.14$ $(\mathrm{H}-8)$ to $\delta_{\mathrm{C}} 172.3(\mathrm{C}=\mathrm{O})$ suggested that the acetyl group was located at C-8. Accordingly, the structure of $\mathbf{1 3}$ was determined to be 8 -acetylerythsotrine. The molecular formula of
14 was dirermined to be $\mathrm{C}_{20} \mathrm{H}_{21} \mathrm{NO}_{5}$ by the HRESIMS $\mathrm{m} / \mathrm{z}$ at $378.1313[\mathrm{M}+\mathrm{Na}]^{+}$. The $1 \mathrm{D}$ NMR spectrum gave signals similar to that of erythraline expect for the replacement of a methylene by an acetyl group $\left(\delta_{\mathrm{C}} 35.4\right.$ and $\left.\delta_{\mathrm{C}} 172.3\right)$. In the HMBC spectrum, the correlations from $\delta_{\mathrm{H}} 4.07(\mathrm{H}-8)$ to $\delta_{\mathrm{C}}$ $172.3(\mathrm{COOH})$ and $\delta_{\mathrm{H}} 2.74\left(\mathrm{CH}_{2} \mathrm{COOH}\right)$ to $\delta_{\mathrm{C}} 65.4(\mathrm{C}-8)$ and $\delta_{\mathrm{C}} 172.3(\mathrm{COOH})$ confirmed that 14 was an 8 -acetyl derivative of erythraline.

The configurations of $\mathrm{H}-8$ for compound 1-14 were determined to be $\beta$ based on ROESY experiments with correlations of $\mathrm{H}-3 \beta / \mathrm{H}-4_{\mathrm{eq}}, \mathrm{H}-4_{\mathrm{eq}} / \mathrm{H}-10_{\mathrm{ax}}$ and $\mathrm{H}-10_{\mathrm{eq}} / \mathrm{H}-8$ (Fig. 2). Further, together with $5 S$-configuration in all Erythrina alkaloids [18], so absolute configuration of alkaloids 1-14 could be determined.

Since N-containing compounds were main candicates of anticancer and hypoglycemic drugs, so alkaloids 1-14 were evaluated for their cytotoxicity against human A-549 lung cancer, SGC-7901 gastric cancer, and HeLa cell lines using the MTT method. In addition, their hypoglycemic activity on 3T3-L1 myoblasts cell were screened. Unfortunately, none of them showed positive activity. Alkaloids 1-14 possessed acetonyl, acetyl methyl, acetate, or methyl formate groups, which indicated they were artificial products. Without considering the artifitial units, these alkaloids are known. Duing the extraction and isolation, methanol, acetone, petroleum ether, especial ethyl acetate, were used as solvents. Accordingly, acetone and residual of acetic acid, methyl acetate and methyl formate in above solvents would become reaction reagents. Alkaloids 1-6 and 9-14 were formed firstly through an iminium immediate by oxidation, then by nucleophilic attack from carbanion of acetone, acetic acid, and methyl acetate in base condition. On the other hand, the iminium immediate could be tautomerized to inmine and

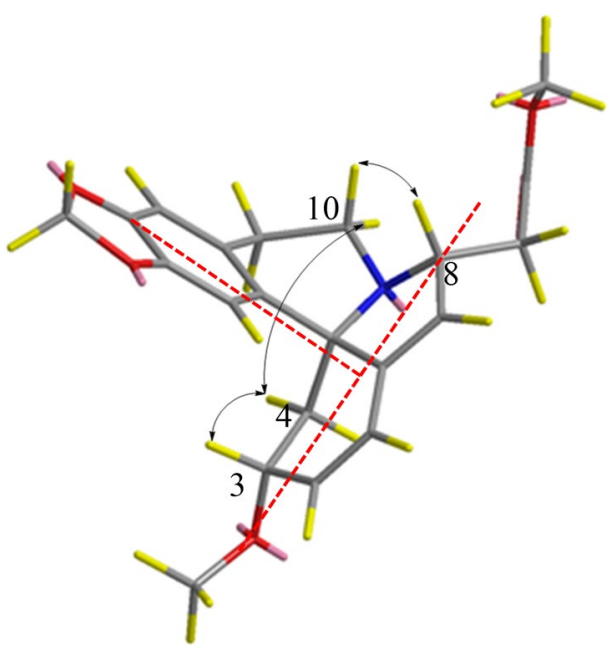

Fig. 2 Selected NOE interaction of alkaloid 9 
attacked to methyl formate, generating the carbomethoxy substitued products (7-8) (Fig. 3).

\section{Experimental Section}

\subsection{General Experimental Procedures}

Optical rotations were measured with a Jasco p-1020 digital polarimeter. UV spectra were recorded on a Shimadzu 2401PC spectrophotometer. IR spectra were obtained on a Bruker Tensor 27 infrared spectrophotometer with $\mathrm{KBr}$ pellets. ${ }^{1} \mathrm{H},{ }^{13} \mathrm{C}$ and $2 \mathrm{D}$ NMR spectra were obtained on Bruker AV-600, AVANCE III-500 and $400 \mathrm{MHz}$ spectrometers with $\mathrm{SiMe}_{4}$ as an internal standard. Chemical shifts $(\delta)$ were expressed in $\mathrm{ppm}$ with reference to the solvent signals. MS data were recorded on an UPLC-IT-TOF MS. Column chromatography (CC) was performed on either silica gel (200-300 mesh, Qingdao Marine Chemical Co., Ltd., Qingdao, China) or RP-18 silica gel (20-45 $\mu$ m, Fuji Silysia Chemical Ltd., Japan). Fractions were monitored by TLC on silica gel plates (GF254, Qingdao Marine Chemical Co., Ltd., Qingdao, China), and spots were visualized with Dragendorff's reagent spray. MPLC was performed using a Buchi pump system coupled with RP-18 silica gelpacked glass columns $(15 \times 230$ and $26 \times 460 \mathrm{~mm}$, respectively). HPLC was performed using Waters 1525 pumps coupled with analytical or preparative Sunfire $\mathrm{C}_{18}$ columns $(4.6 \times 150$ and $19 \times 250 \mathrm{~mm}$, respectively). The HPLC system employed a Waters 2998 photodiode array detector and a Waters fraction collector III.

\subsection{Plant Material}

Flowers of E. variegata Linn and E. crista-galli Linn were collected in February and April, respectively, 2014 in Simao of Yunnan Province, People's Republic of China. Leaves and flowers of Erythrina arborescens Roxb. Hort. Beng were collected in October 2014 in Jianshui of Yunnan Province. These plant samples were identified by Dr. Chun-Xia Zeng. The voucher specimens (Cai20140207, Cai20140407, Cai20141003 and Cai20141004) have been deposited in the State Key Laboratory of Phytochemistry and Plant Resources in West China, Kunming Institute of Botany, the Chinese Academy of Sciences.

\subsection{Extraction and Isolation}

The dried and powdered flowers of E. variegata $(10.0 \mathrm{~kg})$ were extracted with $90 \% \mathrm{MeOH}(25 \mathrm{~L})$ for three times. The extracts were concentrated under reduced pressure, and then dissolved in $2 \%$ acetic acid to adjust $\mathrm{pH}$ to $2-3$ and then partitioned twice with EtOAc. The aqueous layers were basified with $\mathrm{NH}_{3} \cdot \mathrm{H}_{2} \mathrm{O}$ to adjust $\mathrm{pH}$ to $8-9$ and then extracted with EtOAc to give a crude alkaloid fraction $(110 \mathrm{~g})$. The crude alkaloid was subjected to column chromatography (CC) over silica gel with gradient $\mathrm{CHCl}_{3}$-Acetone (1:0 to 1:1) to afford seven fractions (Fr. I-Fr. VII). Fr. I (6.1 g) was divided into 2 subfractions (Fr. I-1-Fr. I-2) by using RP-MPLC eluting

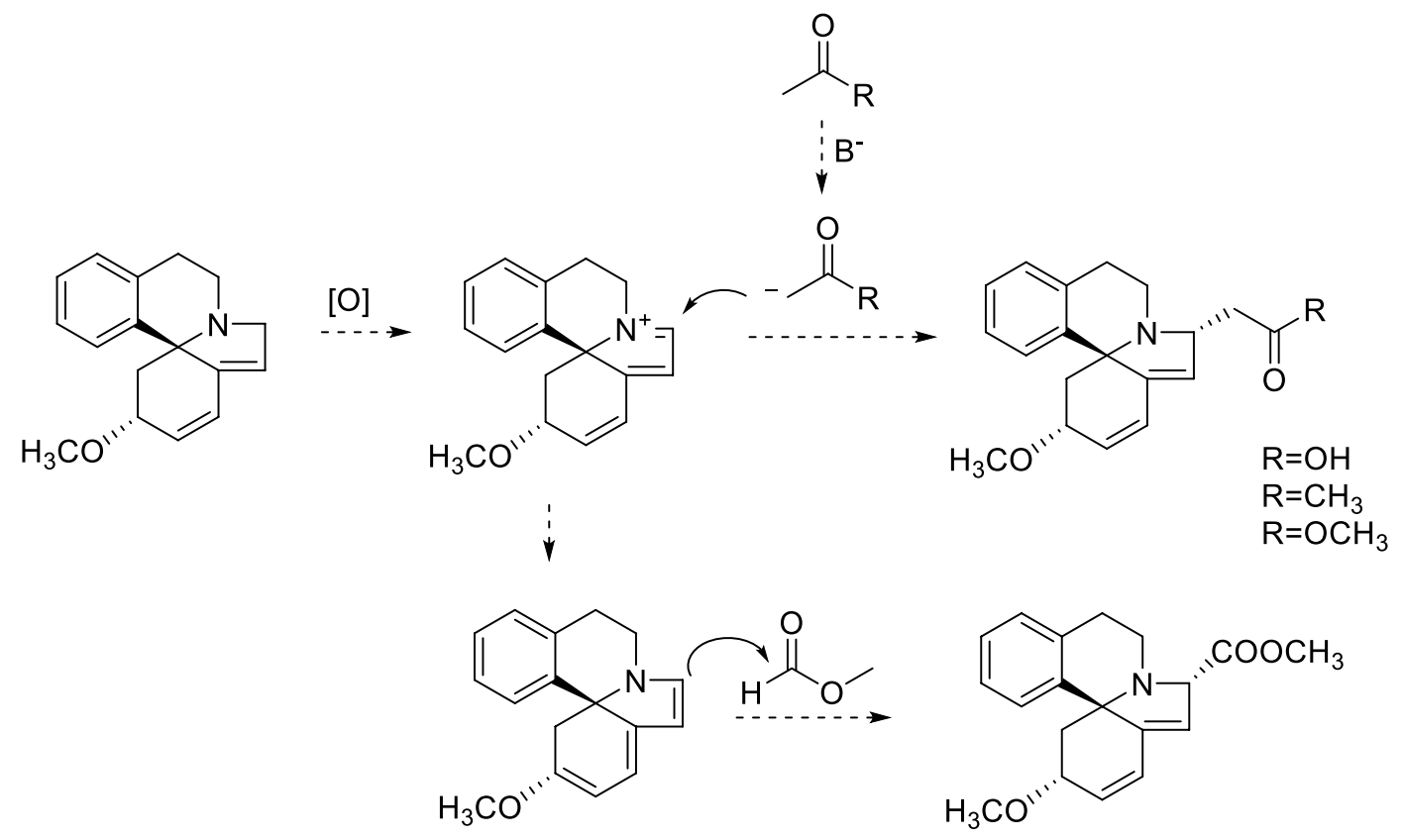

Fig. 3 Possible formation of two typically artificial Erythrina alkaloids 
with $\mathrm{MeOH}-\mathrm{H}_{2} \mathrm{O}(50-100 \%)$. Fr. I-2 was isolated by preparative $\mathrm{C}_{18} \mathrm{HPLC}$ column with a gradient of $\mathrm{MeOH}-\mathrm{H}_{2} \mathrm{O}$ $(60: 40-70: 30, \mathrm{v} / \mathrm{v})$ to obtain $\mathbf{9}(35 \mathrm{mg})$ and $\mathbf{1 1}(41 \mathrm{mg})$. Fr. II $(4.5 \mathrm{~g})$ was separated using $\mathrm{C}_{18}$ MPLC column with a gradient of $\mathrm{MeOH}-\mathrm{H}_{2} \mathrm{O}(40: 60-90: 40, \mathrm{v} / \mathrm{v})$ to afford $\mathbf{1 0}(35 \mathrm{mg})$ and $8(13 \mathrm{mg})$. Fr. IV $(8.5 \mathrm{~g})$ was fractionated by $\mathrm{C}_{18}$ MPLC column with a gradient of $\mathrm{MeOH}-\mathrm{H}_{2} \mathrm{O}$ (10:90-90:10, v/v) to give six subfractions (Fr. IV-1-Fr. IV-6). Fr. IV-2 was subjected to a preparative $\mathrm{C}_{18}$ HPLC column with a gradient of $\mathrm{MeOH}-\mathrm{H}_{2} \mathrm{O}(50: 50-60: 40, \mathrm{v} / \mathrm{v})$ to afford $6(20 \mathrm{mg})$ and $5(32 \mathrm{mg})$ Fr. IV-4 was subjected to a preparative $\mathrm{C}_{18}$ HPLC column with a gradient of $\mathrm{MeOH}-\mathrm{H}_{2} \mathrm{O}(70: 30-80: 20$, v/v) to give $1(5 \mathrm{mg})$. Fr. $\mathrm{V}(12 \mathrm{~g})$ was chromatographed on a $\mathrm{C}_{18}$ MPLC column eluted with a gradient of $\mathrm{MeOH}-\mathrm{H}_{2} \mathrm{O}$ $(10: 80-100: 0, v / v)$ to give six subfractions (Fr. V-1-Fr.V6). $2(29 \mathrm{mg})$ and $3(21 \mathrm{mg})$ was obtained from Fr.V-5 using a preparative $\mathrm{C}_{18}$ HPLC column with a gradient of $\mathrm{MeOH}-\mathrm{H}_{2} \mathrm{O}$ (65:35-25:75, v/v).

Flowers of E. crista-galli $(11 \mathrm{~kg})$ were powdered and extracted with $90 \% \mathrm{MeOH}(25 \mathrm{~L})$ for three times. The extract was concentrated in vacuo to give a brown residue. The crude alkaloid $(90 \mathrm{~g})$ were obtained using the same acid-base treatment method described above, and then subjected to column chromatography (CC) over silica gel and eluted with gradient $\mathrm{CHCl}_{3}$-Acetone (1:0 to 1:1) to afford four fractions (Fr. I-Fr. IV). Fr. I (12.1 g) was further chromatographed on a $\mathrm{C}_{18}$ MPLC column eluted with a gradient of $\mathrm{MeOH}-\mathrm{H}_{2} \mathrm{O}(50: 50-100: 0, \mathrm{v} / \mathrm{v})$ to give the two subfractions (Fr. I-1-Fr. I-2). Alkaloid 12 (51 mg) was obtained from Fr. I-1 using a column chromatography (CC) over silica gel and eluted with petroleum ether-acetone (4:1).

Crude alkaloid extract $(85.2 \mathrm{~g})$ and $(62.5 \mathrm{~g})$ were obtained from the leaves $(15.8 \mathrm{~kg})$ and flowers $(6.5 \mathrm{~kg})$ of Erythrina arborescens, respectively. The crude alkaloid of leaves was divided into nine fractions (Fr. I-Fr. IX). Fr. V (7.1 g) was fractionated by $\mathrm{C}_{18}$ MPLC column with a gradient of $\mathrm{MeOH}-\mathrm{H}_{2} \mathrm{O}(20: 80-80: 20, \mathrm{v} / \mathrm{v})$ to give three subfractions (Fr. V-1-Fr. V-3). Fr. V-3 was subjected to a preparative $\mathrm{C}_{18}$ HPLC column with a gradient of $\mathrm{MeOH}-\mathrm{H}_{2} \mathrm{O}$ (60:40-70:30, $\mathrm{v} / \mathrm{v})$ to afford $4(1 \mathrm{mg})$ and $\mathbf{1 4}(5 \mathrm{mg})$. The crude alkaloid of flowers was divided into seven fractions (Fr. I-Fr. VII). 7 was obtained from Fr. II by $\mathrm{C}_{18}$ MPLC column with a gradient of $\mathrm{MeOH}-\mathrm{H}_{2} \mathrm{O}(40: 60-100: 0, \mathrm{v} / \mathrm{v})$ and then purified by preparative $\mathrm{C}_{18}$ HPLC column with a gradient $\mathrm{MeOH}-\mathrm{H}_{2} \mathrm{O}$ (50:50-60:40, v/v). Fr. IV (4.5 g) was chromatographed on a $\mathrm{C}_{18}$ MPLC column eluted with a gradient of $\mathrm{MeOH}-\mathrm{H}_{2} \mathrm{O}$ $(20: 80-70: 30, \mathrm{v} / \mathrm{v})$ to give four subfractions (Fr. IV-1-Fr. IV-4). Fr. IV-3 was further purified by a preparative $\mathrm{C}_{18}$ HPLC column with a gradient of $\mathrm{MeCN}-\mathrm{H}_{2} \mathrm{O}$ (25:75-35:65, $\mathrm{v} / \mathrm{v})$ to afford $13(20 \mathrm{mg})$.

8 $\alpha$-(2-oxopropyl)-erythrivarine A (1): white powder; $[\alpha]_{\mathrm{D}}^{20}-121.2(c 0.2, \mathrm{MeOH}) ; \mathrm{UV}(\mathrm{MeOH}) \lambda_{\max }(\log \varepsilon)$ 204 (4.26), 239 (3.88) and 290 (3.46) nm; IR (KBr) $\nu_{\text {max }}$
$3441,2924,1640,1503,1480,1226,1100,1041 \mathrm{~cm}^{-1} ;{ }^{1} \mathrm{H}$ $(600 \mathrm{MHz})$ and ${ }^{13} \mathrm{C}$ NMR $(150 \mathrm{MHz})$ data (acetone- $\left.d_{6}\right)$, see Table 1; positive HRESIMS $m / z 681.2811[\mathrm{M}+\mathrm{H}]^{+}$(calcd. for $\mathrm{C}_{39} \mathrm{H}_{41} \mathrm{~N}_{2} \mathrm{O}_{9}, 681.2110$ ).

8 $\alpha$-(2-oxopropyl)-11'- $O$-methyl-erythrivarine A (2): white powder; $[\alpha]_{\mathrm{D}}^{20}-114.1(c 0.1, \mathrm{MeOH}) ; \mathrm{UV}(\mathrm{MeOH})$ $\lambda_{\max }(\log \varepsilon) 203$ (4.12), 238 (3.66) and 289 (3.43) nm; IR (KBr) $\nu_{\max } 3441,1639,1490,1234,1101,1040 \mathrm{~cm}^{-1} ;{ }^{1} \mathrm{H}$ $(600 \mathrm{MHz})$ and ${ }^{13} \mathrm{C}$ NMR $(150 \mathrm{MHz})$ data $\left(\right.$ acetone- $\left.d_{6}\right)$, see Table 1; positive HRESIMS $\mathrm{m} / z 695.2968[\mathrm{M}+\mathrm{H}]^{+}$(calcd. for $\mathrm{C}_{40} \mathrm{H}_{43} \mathrm{~N}_{2} \mathrm{O}_{9}, 695.2969$ ).

8 $\alpha$-(2-oxopropyl)-11'-epi- $O$-methyl-erythrivarine A (3): white powder; $[\alpha]_{\mathrm{D}}^{20}-165.2(c 0.1, \mathrm{MeOH}) ; \mathrm{UV}(\mathrm{MeOH})$ $\lambda_{\max }(\log \varepsilon) 204$ (4.22), 238 (3.88) and 289 (3.46) nm; IR (KBr) $\nu_{\max } 3441,2924,1629,1503,1482,1234,1100$, $1040 \mathrm{~cm}^{-1} ;{ }^{1} \mathrm{H}(600 \mathrm{MHz})$ and ${ }^{13} \mathrm{C}$ NMR $(150 \mathrm{MHz})$ data (acetone- $d_{6}$ ), see Table 1 ; positive HRESIMS $m / z 695.2970$ $[\mathrm{M}+\mathrm{H}]^{+}$(calcd. for $\mathrm{C}_{40} \mathrm{H}_{43} \mathrm{~N}_{2} \mathrm{O}_{9}, 695.2969$ ).

8 $\alpha$-(2-oxopropyl)-erythrinine (4): white powder; $[\alpha]_{\mathrm{D}}^{20}+133.0(c 0.2, \mathrm{MeOH}) ; \mathrm{UV}(\mathrm{MeOH}) \lambda_{\max }(\log \varepsilon)$ 204 (4.71), 239 (3.63) and 289 (3.32) nm; IR (KBr) $\nu_{\max }$ 2930, 1630, 1503, $1489 \mathrm{~cm}^{-1} ;{ }^{1} \mathrm{H}(600 \mathrm{MHz})$ and ${ }^{13} \mathrm{C}$ NMR $(150 \mathrm{MHz})$ data (acetone- $d_{6}$ ), see Tables 2 and 4; positive HRESIMS $m / z 370.1651[\mathrm{M}+\mathrm{H}]^{+}$(calcd. for $\mathrm{C}_{21} \mathrm{H}_{24} \mathrm{NO}_{5}$, $370.1652)$.

8 $\alpha$-(2-oxopropyl)-erythraline (5): white powder; $[\alpha]_{\mathrm{D}}^{23}+80.5(c 0.10, \mathrm{MeOH}) ; \mathrm{UV}(\mathrm{MeOH}) \lambda_{\max }(\log \varepsilon) 201$ (4.11), 238 (2.37), 289(1.29) nm; IR (KBr) $\nu_{\max } 1712,1480$, $1423 \mathrm{~cm}^{-1}$; ${ }^{1} \mathrm{H}(600 \mathrm{MHz})$ and ${ }^{13} \mathrm{C}$ NMR $(150 \mathrm{MHz})$ data (acetone- $d_{6}$ ), see Tables 2 and 4; positive HRESIMS $\mathrm{m} / \mathrm{z}$ $354.1709[\mathrm{M}+\mathrm{H}]^{+}$(calcd. for $\mathrm{C}_{21} \mathrm{H}_{23} \mathrm{NO}_{4}, 354.1707$ ).

8 $\alpha$-(2-oxopropyl)-11-methoxy-erythraline (6): white powder; $[\alpha]_{\mathrm{D}}^{20}+95.3(c 0.1, \mathrm{MeOH}) ; \mathrm{UV}(\mathrm{MeOH}) \lambda_{\max }$ $(\log \varepsilon) 204$ (4.76), 238 (3.74) and 288 (3.48) nm; IR (KBr) $\nu_{\max } 1631,1504,1483 \mathrm{~cm}^{-1} ;{ }^{1} \mathrm{H}(600 \mathrm{MHz})$ and ${ }^{13} \mathrm{C} \mathrm{NMR}$ $(150 \mathrm{MHz})$ data (acetone- $d_{6}$ ), see Tables 2 and 4; positive HRESIMS $m / z 384.1806[\mathrm{M}+\mathrm{H}]^{+}$(calcd. for $\mathrm{C}_{22} \mathrm{H}_{26} \mathrm{NO}_{5}$, 384.1805).

8 $\alpha$-carbomethoxyerysotrine (7): white powder; $[\alpha]_{\mathrm{D}}^{22}+74.0\left(c 0.21, \mathrm{CH}_{3} \mathrm{OH}\right) ; \mathrm{UV}\left(\mathrm{CH}_{3} \mathrm{OH}\right) \lambda_{\max }(\log \varepsilon)$ 203 (3.79), 225 (3.45) and $277(3.05) \mathrm{nm} ;{ }^{1} \mathrm{H}(400 \mathrm{~Hz})$ and ${ }^{13} \mathrm{C}(125 \mathrm{~Hz})$ NMR data (acetone- $\left.d_{6}\right)$, Tables 2 and 4; Positive ESIMS $\mathrm{m} / \mathrm{z} 394[\mathrm{M}+\mathrm{Na}]^{+}$, HRESIMS $\mathrm{m} / \mathrm{z} .394 .1626$ $[\mathrm{M}+\mathrm{Na}]^{+}$; (calcd. for $\mathrm{C}_{21} \mathrm{H}_{25} \mathrm{NO}_{5} \mathrm{Na}, 394.1625$ ).

8 $\alpha$-carbomethoxyerythrinine (8): white powder; $[\alpha]_{\mathrm{D}}^{20}+118.3(c 0.1, \mathrm{MeOH}) ; \mathrm{UV}(\mathrm{MeOH}) \lambda_{\max }(\log \varepsilon)$ 205 (4.69), 239 (3.79) and 289 (3.51) nm; IR (KBr) $\nu_{\max }$ 2923, 1630, 1503, $1488 \mathrm{~cm}^{-1} ;{ }^{1} \mathrm{H}(600 \mathrm{MHz})$ and ${ }^{13} \mathrm{C}$ NMR $\left(150 \mathrm{MHz}\right.$ ) data (acetone- $d_{6}$ ), see Tables 2 and 4; positive HRESIMS $m / z 372.1444[\mathrm{M}+\mathrm{H}]^{+}$(calcd. for $\mathrm{C}_{20} \mathrm{H}_{22} \mathrm{NO}_{6}$, 372.1443).

$8 \boldsymbol{\alpha}$-acetatemethoxyerythraline $(9)$ : white powder; $[\alpha]_{\mathrm{D}}^{20}+171(c 0.1, \mathrm{MeOH}) ; \mathrm{UV}(\mathrm{MeOH}) \lambda_{\max }(\log \varepsilon) 204$ 
Table $2{ }^{1} \mathrm{H}$ NMR spectroscopic data for $\mathbf{4 - 8}$ in acetone- $d_{6}(\delta$ in ppm and $J$ in $\mathrm{Hz})$

\begin{tabular}{|c|c|c|c|c|c|}
\hline Entry & $\delta_{\mathrm{H}}(\mathbf{4})^{\mathrm{a}}$ & $\delta_{\mathrm{H}}(\mathbf{5})^{\mathrm{a}}$ & $\delta_{\mathrm{H}}(\mathbf{6})^{\mathrm{a}}$ & $\delta_{\mathrm{H}}(7)^{\mathrm{b}}$ & $\delta_{\mathrm{H}}(\mathbf{8})^{\mathrm{a}}$ \\
\hline 1 & $6.55, \mathrm{dd}(10.2,2.4)$ & $6.72, \mathrm{dd}(10.2,2.4)$ & $6.55, \mathrm{dd}(10.2,1.8)$ & $6.60 \mathrm{dd}(10.2,1.9)$ & $6.59, \mathrm{dd}(10.2,2.4)$ \\
\hline 2 & $6.01, \mathrm{~d}(10.2)$ & $6.68, \mathrm{~d}(10.2)$ & $6.03, \mathrm{~d}(10.2)$ & $6.10, \mathrm{~d}(10.2)$ & $6.07, \mathrm{~d}(10.2)$ \\
\hline 3 & $3.79, \mathrm{~m}$ & $3.85, \mathrm{~m}$ & $3.92, \mathrm{~m}$ & $3.97, \mathrm{~m}$ & $3.85, \mathrm{~m}$ \\
\hline \multirow[t]{2}{*}{4} & $2.38, \mathrm{dd}(11.4,5.4)$ & $2.48, \mathrm{dd}(11.4,5.6)$ & 2.46 , dd $(11.4,5.4)$ & $2.53, \mathrm{dd}(11.2,5.7)$ & $2.45, \mathrm{dd}(11.4,5.4)$ \\
\hline & $1.65, \mathrm{t}(11.4)$ & $1.68, \mathrm{t}(11.4)$ & $1.66, \mathrm{t}(11.4)$ & $1.78, \mathrm{t}(11.2)$ & $1.73, \mathrm{t}(11.4)$ \\
\hline 7 & $5.67, \mathrm{~s}$ & $5.63, \mathrm{~s}$ & $5.64, \mathrm{~s}$ & $5.67, \mathrm{~s}$ & $5.71, \mathrm{~s}$ \\
\hline 8 & $4.20, \mathrm{~m}$ & $3.98, \mathrm{~m}$ & $4.33, \mathrm{~m}$ & $4.33, \mathrm{~s}$ & $4.68, \mathrm{~s}$ \\
\hline \multirow[t]{2}{*}{10} & $3.48, \mathrm{dd}(13.8,4.8)$ & $3.38, \mathrm{~m}$ & 3.39 , dd $(13.8,4.2)$ & $3.49, \mathrm{~m}$ & $3.57, \mathrm{dd}(13.2,4.8)$ \\
\hline & $2.68, \mathrm{dd}(13.8,6,6)$ & 2.77 (overlap) & 3.09 , dd $(13.8,4.2)$ & $3.02 \mathrm{dd}(12.9,5.7)$ & $2.92, \mathrm{dd}(13.2,4.8)$ \\
\hline \multirow[t]{2}{*}{11} & $4.75, \mathrm{~m}$ & 2.77 (overlap) & $4.18, \mathrm{t}(4.2)$ & $2.93, \mathrm{~m}$ & $4.77, \mathrm{~m}$ \\
\hline & & $2.65, \mathrm{~m}$ & & $264, \mathrm{~m}$ & \\
\hline 14 & $6.70, \mathrm{~s}$ & $6.72, \mathrm{~s}$ & $6.74, \mathrm{~s}$ & $6.84, \mathrm{~s}$ & $6.73, \mathrm{~s}$ \\
\hline 17 & $7.05, \mathrm{~s}$ & $6.68, \mathrm{~s}$ & $6.89, \mathrm{~s}$ & $6.76, \mathrm{~s}$ & $7.04, \mathrm{~s}$ \\
\hline $3-\mathrm{OCH}_{3}$ & $3.25, \mathrm{~s}$ & $3.28, \mathrm{~s}$ & $3.28, \mathrm{~s}$ & $3.28, \mathrm{~s}$ & $3.23, \mathrm{~s}$ \\
\hline $11-\mathrm{OCH}_{3}$ & & & $3.55, \mathrm{~s}$ & & \\
\hline $11-\mathrm{OH}$ & $4.72, \mathrm{~d}(4.8)$ & & & & 4.64 , br s \\
\hline $15-\mathrm{OCH}_{3}$ & & & & $3.70, \mathrm{~s}$ & \\
\hline $16-\mathrm{OCH}_{3}$ & & & & $3.97, \mathrm{~s}$ & \\
\hline \multirow[t]{2}{*}{$\mathrm{OCH}_{2} \mathrm{O}$} & $6.01, \mathrm{~s}$ & $5.92, \mathrm{~s}$ & $5.96, \mathrm{~s}$ & & $5.95, \mathrm{~s}$ \\
\hline & $5.99, \mathrm{~s}$ & $5.90, \mathrm{~s}$ & $5.94, \mathrm{~s}$ & & $5.94, \mathrm{~s}$ \\
\hline \multirow[t]{2}{*}{$\mathrm{CH}_{2} \mathrm{COCH}_{3}$} & $2.90, \mathrm{dd}(15.6,4.8)$ & 2.85 (overlap) & 2.94 , overlap & & \\
\hline & $2.55, \mathrm{dd}(15.6,4.8)$ & $2.58, \mathrm{dd}(16.8,8.0)$ & $2.55, \mathrm{dd}(15.6,9.0)$ & & \\
\hline $\mathrm{CH}_{2} \mathrm{COCH}_{3}$ & $2.13, \mathrm{~s}$ & $2.13, \mathrm{~s}$ & $2.12, \mathrm{~s}$ & & \\
\hline $\mathrm{COOCH}_{3}$ & & & & $3.78, \mathrm{~s}$ & $3.72, \mathrm{~s}$ \\
\hline
\end{tabular}

${ }^{\mathrm{a} 1} \mathrm{H}$ NMR recorded in $600 \mathrm{MHz}$

${ }^{\mathrm{b} 1} \mathrm{H} \mathrm{NMR}$ recorded in $400 \mathrm{MH}$

(4.78), 239 (3.88) and 290 (3.52) nm; IR (KBr) $\nu_{\max } 1628$, $1501,1489 \mathrm{~cm}^{-1} ;{ }^{1} \mathrm{H}(600 \mathrm{MHz})$ and ${ }^{13} \mathrm{C}$ NMR $(150 \mathrm{MHz})$ data (acetone- $d_{6}$ ), see Tables 3 and 4; positive HRESIMS $m / z 370.1652[\mathrm{M}+\mathrm{H}]^{+}$(calcd. for $\mathrm{C}_{21} \mathrm{H}_{24} \mathrm{NO}_{5}, 370.1653$ ).

$8 \alpha$-acetatemethoxyerythrinine (10): white powder; $[\alpha]_{\mathrm{D}}^{20}+89.4(c$ 0.1, $\mathrm{MeOH}) ; \mathrm{UV}(\mathrm{MeOH}) \lambda_{\max }(\log \varepsilon) 204$ (4.65), 238 (3.68) and 290 (3.33) nm; IR (KBr) $\nu_{\max } 2924$, $1628,1488 \mathrm{~cm}^{-1} ;{ }^{1} \mathrm{H}(600 \mathrm{MHz})$ and ${ }^{13} \mathrm{C}$ NMR $(150 \mathrm{MHz})$ data (acetone- $d_{6}$ ), see Tables 3 and 4; positive HRESIMS $m / z 386.1599[\mathrm{M}+\mathrm{H}]^{+}$(calcd. for $\mathrm{C}_{21} \mathrm{H}_{24} \mathrm{NO}_{6}, 386.1598$ ).

$8 \alpha$-acetatemethoxy-11 $\beta$-methoxyerythraline (11): white powder; $[\alpha]_{\mathrm{D}}^{20}+154.2(c 0.2, \mathrm{MeOH}) ; \mathrm{UV}(\mathrm{MeOH})$ $\lambda_{\max }(\log \varepsilon) 204$ (4.62), 238 (3.74) and 289 (3.41) nm; IR (KBr) $\nu_{\max } 1630,1503,1484 \mathrm{~cm}^{-1} ;{ }^{1} \mathrm{H}(600 \mathrm{MHz})$ and ${ }^{13} \mathrm{C}$ NMR (150 MHz) data (acetone- $d_{6}$ ), see Tables 3 and 4; positive HRESIMS $\mathrm{m} / \mathrm{z} 400.1758[\mathrm{M}+\mathrm{H}]^{+}$(calcd. for $\mathrm{C}_{22} \mathrm{H}_{26} \mathrm{NO}_{6}$, 400.1757).

$8 \boldsymbol{\alpha}$-acetatemethoxyerysotrine (12): white powder; $[\alpha]_{\mathrm{D}}^{20}+113.3(c 0.1, \mathrm{MeOH}) ; \mathrm{UV}(\mathrm{MeOH}) \lambda_{\max }(\log \varepsilon) 204$ (4.72), 239 (3.66) and 288 (3.51) nm; IR (KBr) $\nu_{\max } 1628$, $1503,1488 \mathrm{~cm}^{-1} ;{ }^{1} \mathrm{H}(600 \mathrm{MHz})$ and ${ }^{13} \mathrm{C}$ NMR $(150 \mathrm{MHz})$ data (acetone- $d_{6}$ ), see Tables 3 and 4; positive HRESIMS $m / z, 386.1964[\mathrm{M}+\mathrm{H}]^{+}$(calcd. for $\mathrm{C}_{22} \mathrm{H}_{28} \mathrm{NO}_{5}, 386.1965$ ).

$8 \boldsymbol{\alpha}$-acetylerythsotrine (13): white powder; $\mathrm{C}_{21} \mathrm{H}_{25} \mathrm{NO}_{5}$; $[\alpha]_{\mathrm{D}}^{22}+5.2\left(\mathrm{c} 0.18, \mathrm{CH}_{3} \mathrm{OH}\right) ; \mathrm{UV}\left(\mathrm{CH}_{3} \mathrm{OH}\right) \lambda_{\max }(\log \varepsilon) 203$ (3.90), 229 (3.56) and $282(2.93) \mathrm{nm} ;{ }^{1} \mathrm{H}(400 \mathrm{~Hz})$ and ${ }^{13} \mathrm{C}$ $(125 \mathrm{~Hz})$ NMR data (acetone- $d_{6}$ ), Tables 3 and 4; Positive ESIMS $m / z 394[\mathrm{M}+\mathrm{Na}]^{+}$, HRESIMS $\mathrm{m} / z .394 .1628$ $[\mathrm{M}+\mathrm{Na}]^{+}$; (calcd. for $\mathrm{C}_{21} \mathrm{H}_{25} \mathrm{NO}_{5} \mathrm{Na}, 394.1625$ ).

$8 \boldsymbol{\alpha}$-acetylerythraline $(\mathbf{1 4})$ : white powder; $[\alpha]_{\mathrm{D}}^{20}+105$ (c 0.1, MeOH); UV (MeOH) $\lambda_{\max }(\log \varepsilon) 204$ (4.71), 249 (3.72) and $289(3.62) \mathrm{nm}$; IR (KBr) $\nu_{\max } 3341,1639,1503$, $1442 \mathrm{~cm}^{-1}$; ${ }^{1} \mathrm{H}(600 \mathrm{MHz})$ and ${ }^{13} \mathrm{C}$ NMR $(150 \mathrm{MHz})$ data (acetone- $d_{6}$ ), see Tables 3 and 4; positive HRESIMS $\mathrm{m} / \mathrm{z}$ $378.1313[\mathrm{M}+\mathrm{H}]^{+}$(calcd. for $\mathrm{C}_{20} \mathrm{H}_{22} \mathrm{NO}_{5}, 378.1314$ ).

\subsection{Cytotoxicity}

The human A-549 lung cancer, SGC-7901 gastric cancer, and HeLa cell lines were used in the cytotoxic assay. These cells were grown in DMEM media (HyClone, USA) supplemented with $10 \%$ fetal bovine serum (HyClone, USA) at $37{ }^{\circ} \mathrm{C}$ in $5 \% \mathrm{CO}_{2}$. The cytotoxicity of all alkaloids were 
Table $3{ }^{1} \mathrm{H}$ NMR spectroscopic data for $\mathbf{9 - 1 4}$ in acetone- $d_{6}(\delta$ in ppm, $J$ in $\mathrm{Hz})$

\begin{tabular}{|c|c|c|c|c|c|c|}
\hline Entry & $\delta_{\mathrm{H}}(\boldsymbol{9})^{\mathrm{a}}$ & $\delta_{\mathrm{H}}(\mathbf{1 0})^{\mathrm{a}}$ & $\delta_{\mathrm{H}}(\mathbf{1 1})^{\mathrm{a}}$ & $\delta_{\mathrm{H}}(12)^{\mathrm{a}}$ & $\delta_{\mathrm{H}}(13)^{\mathrm{b}}$ & $\delta_{\mathrm{H}}(14)^{\mathrm{a}}$ \\
\hline 1 & $6.54, \mathrm{dd}(10.2,2.4)$ & $6.55, \mathrm{dd}(10.2,2.4)$ & $6.56, \mathrm{dd}(10.2,1.8)$ & $6.57, \mathrm{dd}(10.2,2.4)$ & $6.60, \mathrm{~d}(10.2)$ & $6.58, \mathrm{dd}(10.2,2.2)$ \\
\hline 2 & $6.00, \mathrm{~d}(10.2)$ & $5.99, \mathrm{~d}(10.2)$ & $6.04, \mathrm{~d}(10.2)$ & $6.05, \mathrm{~d}(10.2)$ & $6.14, \mathrm{~d}(10.20$ & $6.11, \mathrm{~d}(10.2)$ \\
\hline 3 & $3.8, \mathrm{~m}$ & $3.77, \mathrm{~m}$ & $3.91, \mathrm{~m}$ & $4.01, \mathrm{~m}$ & $4.09, \mathrm{~m}$ & $3.92, \mathrm{~m}$ \\
\hline \multirow[t]{2}{*}{4} & 2.48, dd $(11.4,5.4)$ & 2.38 , overlap & $2.46, \mathrm{dd}(11.4,5.4)$ & $2.50, \mathrm{~m}$ & 2.63, dd $(10.9,5.7)$ & $2.66, \mathrm{dd}(11.4,5.5)$ \\
\hline & $1.69, \mathrm{t}(11.4)$ & $1.64, \mathrm{t}(11.4)$ & $1.66, \mathrm{t}(11.4)$ & $1.69, \mathrm{t}(10.8)$ & $1.78, \mathrm{t}(10.9)$ & $1.77, \mathrm{t}(11.4)$ \\
\hline 7 & $5.66, \mathrm{~s}$ & $5.70, \mathrm{~s}$ & $5.69, \mathrm{~s}$ & $5.64, \mathrm{~s}$ & $5.68, \mathrm{~s}$ & $5.72, \mathrm{~s}$ \\
\hline 8 & $3.94, \mathrm{~m}$ & $4.16, \mathrm{~m}$ & $4.31, \mathrm{~m}$ & $4.05, \mathrm{~m}$ & $4.14, \mathrm{~m}$ & $4.07, \mathrm{~m}$ \\
\hline \multirow[t]{2}{*}{10} & $3.40, \mathrm{~m}$ & $3.50, \mathrm{dd}(12.0,5.4)$ & $3.39, \mathrm{dd}(13.8,4.2)$ & $3.37, \mathrm{~m}$ & $3.49, \mathrm{~m}$ & $3.53, \mathrm{~m}$ \\
\hline & $2.75, \mathrm{~m}$ & $2.65, \mathrm{dd}(12.0,6.6)$ & 3.06 , dd $(13.8,4.2)$ & $2.95, \mathrm{~m}$ & $3.16, \mathrm{~m}$ & $3.03, \mathrm{~m}$ \\
\hline \multirow[t]{2}{*}{11} & 2.84 , overlap & $4.77, \mathrm{~m}$ & $4.19, \mathrm{t}(4.2)$ & $2.96, \mathrm{~m}$ & $3.03, \mathrm{~m}$ & $2.98, \mathrm{~m}$ \\
\hline & 2.65 , overlap & & & $2.57, \mathrm{~m}$ & 2.72 , overlap & $2.84, \mathrm{~m}$ \\
\hline 14 & $6.70, \mathrm{~s}$ & $6.69, \mathrm{~s}$ & $6.90, \mathrm{~s}$ & $6.83, \mathrm{~s}$ & $6.84, \mathrm{~s}$ & $6.73, \mathrm{~s}$ \\
\hline 17 & $6.68, \mathrm{~s}$ & $7.05, \mathrm{~s}$ & $6.74, \mathrm{~s}$ & $6.81, \mathrm{~s}$ & $6.78, \mathrm{~s}$ & $6.74, \mathrm{~s}$ \\
\hline $3-\mathrm{OCH}_{3}$ & $3.25, \mathrm{~s}$ & $3.23, \mathrm{~s}$ & $3.29, \mathrm{~s}$ & $3.28, \mathrm{~s}$ & $3.31, \mathrm{~s}$ & $3.30, \mathrm{~s}$ \\
\hline $11-\mathrm{OCH}_{3}$ & & & $3.55, \mathrm{~s}$ & & & \\
\hline $11-\mathrm{OH}$ & & $4.60, d(5.4)$ & & & & \\
\hline $15-\mathrm{OCH}_{3}$ & & & & $3.78, \mathrm{~s}$ & $3.68, \mathrm{~s}$ & \\
\hline $16-\mathrm{OCH}_{3}$ & & & & $3.67, \mathrm{~s}$ & $3.79, \mathrm{~s}$ & \\
\hline \multirow[t]{2}{*}{$\mathrm{OCH}_{2} \mathrm{O}$} & $5.91, \mathrm{~s}$ & $5.95, \mathrm{~s}$ & $5.96, \mathrm{~s}$ & & & $5.96, \mathrm{~s}$ \\
\hline & $5.89, \mathrm{~s}$ & $5.94, \mathrm{~s}$ & $5.94, \mathrm{~s}$ & & & $5.95, \mathrm{~s}$ \\
\hline \multirow[t]{2}{*}{$\mathrm{CH}_{2} \mathrm{COO}-$} & $2.68, \mathrm{dd}(15.0,4.8)$ & $2.73, \mathrm{dd}(15.0,4.8)$ & $2.81, \mathrm{dd}(15,4.2)$ & $2.72, \mathrm{dd}(15.0,4.8)$ & 2.76 , overlap & $2.74, \mathrm{dd}(16.8,5.8)$ \\
\hline & $2.39, \mathrm{dd}(15.0,7.8)$ & 2.36 , overlap & $2.36, \mathrm{dd}(15,6.0)$ & $2.41, \mathrm{dd}(15.0,7.8)$ & $2.51, \mathrm{dd}(16.5,2.8)$ & $2.51, \mathrm{dd}(16.8,1.8)$ \\
\hline $\mathrm{CH}_{2} \mathrm{COOCH}_{3}$ & $3.61, \mathrm{~s}$ & $3.60, \mathrm{~s}$ & $3.62, \mathrm{~s}$ & $3.63, \mathrm{~s}$ & & \\
\hline
\end{tabular}

${ }^{\mathrm{a} 1} \mathrm{H}$ NMR recorded in $600 \mathrm{MHz}$

${ }^{\mathrm{b} 1} \mathrm{H}$ NMR recorded in $400 \mathrm{MH}$

determined based on the MTT method in 96-well microplates. In short, $100 \mu \mathrm{L}$ adherent cells were seeded into each well and incubated for $12 \mathrm{~h}$ before the addition of the test alkaloids/drug. At the same time, the suspended cells were seeded at an initial density of $1 \times 10^{5}$ cells $/ \mathrm{mL}$ just before the addition of the alkaloids/drug. Each tumor cell line was exposed to a test compound at concentration $20 \mu \mathrm{M}$ in DMSO in triplicate for $48 \mathrm{~h}$, with camptothecin as the positive control. After treatment, cell viability was assessed.

\subsection{Hypoglycemic Activity}

3T3-L1 myoblasts cells were purchased from American Type Culture Collection (Manassas, VA). Cells were maintained in DMEM supplemented with $10 \%$ FBS or CS (for 3T3-L1 cells), 100 units/ml penicillin and $100 \mathrm{mg} / \mathrm{ml}$ streptomycin in $10 \mathrm{~cm}$ diameter dishes in a humidified atmosphere of $95 \%$ air and $5 \% \mathrm{CO}_{2}$ at $37{ }^{\circ} \mathrm{C}$. Cells were maintained in continuous passages by trypsinization of subconfluent cultures and fed fresh medium every $48 \mathrm{~h}$. For differentiation, L6 myoblasts were transferred to DMEM with $2 \%$ FCS in tissue culture plates for 5-6 days, 3T3-L1 cells were exposed to $0.5 \mathrm{mM}$ IBMX, $1 \mathrm{mM}$ dexamethasone, $1 \mathrm{mM}$ rosiglitazone and $1 \mathrm{mg} / \mathrm{mL}$ insulin for 3 days, and $1 \mathrm{mg} / \mathrm{ml}$ insulin for the other day. For glucose uptake assay, cells were serum starved for $4 \mathrm{~h}$ in 96-well plates, followed by incubated with insulin and alkaloids 1-14 for $24 \mathrm{~h}$. Finally, the supernatants of cultured cells were collected and subjected to glucose assay using a commercially kit. The quantified values were normalized based on the results of the MTS assay. 
Table $4{ }^{13} \mathrm{C}$ NMR spectroscopic data from $\mathbf{4}$ to $\mathbf{1 4}$ in acetone- $d_{6}(\delta$ in ppm)

\begin{tabular}{|c|c|c|c|c|c|c|c|c|c|c|c|}
\hline Entry & $\delta_{\mathrm{C}}(\mathbf{4})^{\mathrm{a}}$ & $\delta_{\mathrm{C}}(\mathbf{5})^{\mathrm{a}}$ & $\delta_{\mathrm{C}}(\mathbf{6})^{\mathrm{a}}$ & $\delta_{\mathrm{C}}(7)^{\mathrm{b}}$ & $\delta_{\mathrm{C}}(\mathbf{8})^{\mathrm{a}}$ & $\delta_{\mathrm{C}}(\mathbf{9})^{\mathrm{a}}$ & $\delta_{\mathrm{C}}(\mathbf{1 0})^{\mathrm{a}}$ & $\delta_{\mathrm{C}}(\mathbf{1 1})^{\mathrm{a}}$ & $\delta_{\mathrm{C}}(\mathbf{1 2})^{\mathrm{a}}$ & $\delta_{\mathrm{C}}(\mathbf{1 3})^{\mathrm{b}}$ & $\delta_{\mathrm{C}}(\mathbf{1 4})^{\mathrm{a}}$ \\
\hline 1 & $125.4 \mathrm{~d}$ & $125.6 \mathrm{~d}$ & $125.7 \mathrm{~d}$ & $125.3 \mathrm{~d}$ & $125.2 \mathrm{~d}$ & $125.4 \mathrm{~d}$ & $125.3 \mathrm{~d}$ & $125.5 \mathrm{~d}$ & $125.6 \mathrm{~d}$ & $125.1 \mathrm{~d}$ & $125.0 \mathrm{~d}$ \\
\hline 2 & $133.1 \mathrm{~d}$ & $133.1 \mathrm{~d}$ & $133.1 \mathrm{~d}$ & $134.0 \mathrm{~d}$ & $134.2 \mathrm{~d}$ & $133.1 \mathrm{~d}$ & $133.2 \mathrm{~d}$ & $133.1 \mathrm{~d}$ & $133.2 \mathrm{~d}$ & $134.1 \mathrm{~d}$ & $134.1 \mathrm{~d}$ \\
\hline 3 & $76.9 \mathrm{~d}$ & $77.0 \mathrm{~d}$ & $76.8 \mathrm{~d}$ & $76.9 \mathrm{~d}$ & $76.8 \mathrm{~d}$ & $76.8 \mathrm{~d}$ & $76.9 \mathrm{~d}$ & $76.7 \mathrm{~d}$ & $77.0 \mathrm{~d}$ & $76.6 \mathrm{~d}$ & $76.5 \mathrm{~d}$ \\
\hline 4 & $43.3 \mathrm{t}$ & $43.8 \mathrm{t}$ & $42.7 \mathrm{t}$ & $43.3 \mathrm{t}$ & $43.1 \mathrm{t}$ & $43.8 \mathrm{t}$ & $43.6 \mathrm{t}$ & $42.7 \mathrm{t}$ & $43.4 \mathrm{t}$ & $42.3 \mathrm{t}$ & $42.7 \mathrm{t}$ \\
\hline 5 & $69.3 \mathrm{~s}$ & $69.3 \mathrm{~s}$ & $68.6 \mathrm{~s}$ & $69.4 \mathrm{~s}$ & $69.7 \mathrm{~s}$ & $69.6 \mathrm{~s}$ & $69.7 \mathrm{~s}$ & $68.9 \mathrm{~s}$ & $68.9 \mathrm{~s}$ & $69.1 \mathrm{~s}$ & $69.7 \mathrm{~s}$ \\
\hline 6 & $142.3 \mathrm{~s}$ & $142.6 \mathrm{~s}$ & $142.4 \mathrm{~s}$ & $144.4 \mathrm{~s}$ & $144.2 \mathrm{~s}$ & $142.7 \mathrm{~s}$ & $142.4 \mathrm{~s}$ & $142.4 \mathrm{~s}$ & $142.9 \mathrm{~s}$ & $143.1 \mathrm{~s}$ & $143.0 \mathrm{~s}$ \\
\hline 7 & $127.6 \mathrm{~d}$ & $127.6 \mathrm{~d}$ & $127.9 \mathrm{~d}$ & $121.7 \mathrm{~d}$ & $122.4 \mathrm{~d}$ & $126.9 \mathrm{~d}$ & $127.1 \mathrm{~d}$ & $127.3 \mathrm{~d}$ & $126.7 \mathrm{~d}$ & $125.2 \mathrm{~d}$ & $125.6 \mathrm{~d}$ \\
\hline 8 & $67.7 \mathrm{~d}$ & $65.1 \mathrm{~d}$ & $65.8 \mathrm{~d}$ & $70.5 \mathrm{~d}$ & $73.2 \mathrm{~d}$ & $66.1 \mathrm{~d}$ & $68.5 \mathrm{~d}$ & $66.4 \mathrm{~d}$ & $64.4 \mathrm{~d}$ & $63.9 \mathrm{~d}$ & $65.4 \mathrm{~d}$ \\
\hline 10 & $52.6 \mathrm{t}$ & $43.9 \mathrm{t}$ & $45.2 \mathrm{t}$ & $44.4 \mathrm{t}$ & $53.1 \mathrm{t}$ & $44.2 \mathrm{t}$ & $53.0 \mathrm{t}$ & $45.4 \mathrm{t}$ & $42.6 \mathrm{t}$ & $40.8 \mathrm{t}$ & $42.3 \mathrm{t}$ \\
\hline 11 & $64.7 \mathrm{~d}$ & $26.0 \mathrm{t}$ & $74.8 \mathrm{~d}$ & $24.6 \mathrm{t}$ & $65.1 \mathrm{~d}$ & $26.0 \mathrm{t}$ & $64.8 \mathrm{t}$ & $74.7 \mathrm{~d}$ & $24.6 \mathrm{t}$ & $24.1 \mathrm{t}$ & $25.5 \mathrm{t}$ \\
\hline 12 & $132.2 \mathrm{~s}$ & $129.4 \mathrm{~s}$ & $130.1 \mathrm{~s}$ & $128.0 \mathrm{~s}$ & $133.3 \mathrm{~s}$ & $129.4 \mathrm{~s}$ & $133.5 \mathrm{~s}$ & $130.0 \mathrm{~s}$ & $127.7 \mathrm{~s}$ & $126.8 \mathrm{~s}$ & $128.7 \mathrm{~s}$ \\
\hline 13 & $133.4 \mathrm{~s}$ & $134.0 \mathrm{~s}$ & $133.0 \mathrm{~s}$ & $132.2 \mathrm{~s}$ & $131.9 \mathrm{~s}$ & $133.9 \mathrm{~s}$ & $132.2 \mathrm{~s}$ & $132.9 \mathrm{~s}$ & $132.7 \mathrm{~s}$ & $130.9 \mathrm{~s}$ & $132.2 \mathrm{~s}$ \\
\hline 14 & $105.9 \mathrm{~d}$ & $106.5 \mathrm{~d}$ & $105.9 \mathrm{~d}$ & $110.6 \mathrm{~d}$ & $105.8 \mathrm{~d}$ & $106.4 \mathrm{~d}$ & $105.8 \mathrm{~d}$ & $105.7 \mathrm{~d}$ & $110.6 \mathrm{~d}$ & $110.4 \mathrm{~d}$ & $106.4 \mathrm{~d}$ \\
\hline 15 & $147.3 \mathrm{~s}$ & $146.7 \mathrm{~s}$ & $148.0 \mathrm{~s}$ & $148.2 \mathrm{~s}$ & $147.6 \mathrm{~s}$ & $146.6 \mathrm{~s}$ & $147.3 \mathrm{~s}$ & $147.8 \mathrm{~s}$ & $148.9 \mathrm{~s}$ & $148.5 \mathrm{~s}$ & $147.0 \mathrm{~s}$ \\
\hline 16 & $147.2 \mathrm{~s}$ & $147.0 \mathrm{~s}$ & $147.2 \mathrm{~s}$ & $149.1 \mathrm{~s}$ & $147.5 \mathrm{~s}$ & $146.9 \mathrm{~s}$ & $147.3 \mathrm{~s}$ & $147.1 \mathrm{~s}$ & $148.1 \mathrm{~s}$ & $149.4 \mathrm{~s}$ & $147.5 \mathrm{~s}$ \\
\hline 17 & $107.4 \mathrm{~d}$ & $109.4 \mathrm{~d}$ & $109.0 \mathrm{~d}$ & $113.1 \mathrm{~d}$ & $108.1 \mathrm{~d}$ & $109.3 \mathrm{~d}$ & $107.2 \mathrm{~d}$ & $108.8 \mathrm{~d}$ & $113.0 \mathrm{~d}$ & $113.1 \mathrm{~d}$ & $109.5 \mathrm{~d}$ \\
\hline $3-\mathrm{OCH}_{3}$ & $56.2 \mathrm{q}$ & $56.3 \mathrm{q}$ & $56.3 \mathrm{q}$ & $56.0 \mathrm{q}$ & $56.3 \mathrm{q}$ & $56.1 \mathrm{q}$ & $56.1 \mathrm{q}$ & $56.2 \mathrm{q}$ & $56.0 \mathrm{q}$ & $55.9 \mathrm{q}$ & $56.4 \mathrm{q}$ \\
\hline $11-\mathrm{OCH}_{3}$ & & & $57.9 \mathrm{q}$ & & & & & $57.7 \mathrm{q}$ & & $56.0 \mathrm{q}$ & \\
\hline $15-\mathrm{OCH}_{3}$ & & & & $56.1 \mathrm{q}$ & & & & & $56.1 \mathrm{q}$ & $56.3 \mathrm{q}$ & \\
\hline $16-\mathrm{OCH}_{3}$ & & & & $56.1 \mathrm{q}$ & & & & & $55.9 \mathrm{q}$ & & \\
\hline $\mathrm{OCH}_{2} \mathrm{O}$ & $101.7 \mathrm{t}$ & $101.7 \mathrm{t}$ & $101.9 \mathrm{t}$ & & $101.9 \mathrm{t}$ & $101.5 \mathrm{t}$ & $101.7 \mathrm{t}$ & $101.7 \mathrm{t}$ & & & $101.9 \mathrm{t}$ \\
\hline $\mathrm{CH}_{2} \mathrm{COCH}_{3}$ & $47.8 \mathrm{t}$ & $48.1 \mathrm{t}$ & $47.4 \mathrm{t}$ & & & & & & & $34.9 \mathrm{t}$ & $35.4 \mathrm{t}$ \\
\hline $\mathrm{CH}_{2} \mathrm{COCH}_{3}$ & $207.9 \mathrm{~s}$ & $207.7 \mathrm{~s}$ & $207.7 \mathrm{~s}$ & & & & & & & $172.3 \mathrm{~s}$ & $172.3 \mathrm{~s}$ \\
\hline $\mathrm{CH}_{3} \mathrm{COCH}_{3}$ & $30.8 \mathrm{q}$ & $30.9 \mathrm{q}$ & $30.8 \mathrm{q}$ & & & & & & & & \\
\hline$\left(\mathrm{CH}_{2}\right) \mathrm{COOCH}_{3}$ & & & & & & $39.5 \mathrm{t}$ & $39.3 \mathrm{t}$ & $38.8 \mathrm{t}$ & $39.3 \mathrm{t}$ & & \\
\hline$\left(\mathrm{CH}_{2}\right) \mathrm{COOCH}_{3}$ & & & & $172.1 \mathrm{~s}$ & $172.2 \mathrm{~s}$ & $172.5 \mathrm{~s}$ & $172.4 \mathrm{~s}$ & $172.3 \mathrm{~s}$ & $172.9 \mathrm{~s}$ & & \\
\hline$\left(\mathrm{CH}_{2}\right) \mathrm{COOCH}_{3}$ & & & & $52.0 \mathrm{q}$ & $52.1 \mathrm{q}$ & $51.5 \mathrm{q}$ & $51.5 \mathrm{q}$ & $51.5 \mathrm{q}$ & $51.6 \mathrm{q}$ & & \\
\hline
\end{tabular}

${ }^{\mathrm{a} 13} \mathrm{C}$ NMR recorded in $150 \mathrm{MHz}$

${ }^{\mathrm{b} 13} \mathrm{C}$ NMR recorded in $125 \mathrm{MHz}$

Acknowledgements This project is supported in part by the National Natural Science Foundation of China (31872677). The authors are grateful to Dr. Chun-Xia Zeng for identification of plant samples.

\section{Compliance with Ethical Standards}

Conflicts of interest The authors declare no conflict of interest.

Open Access This article is licensed under a Creative Commons Attribution 4.0 International License, which permits use, sharing, adaptation, distribution and reproduction in any medium or format, as long as you give appropriate credit to the original author(s) and the source, provide a link to the Creative Commons licence, and indicate if changes were made. The images or other third party material in this article are included in the article's Creative Commons licence, unless indicated otherwise in a credit line to the material. If material is not included in the article's Creative Commons licence and your intended use is not permitted by statutory regulation or exceeds the permitted use, you will need to obtain permission directly from the copyright holder. To view a copy of this licence, visit http://creativecommons.org/licenses/by/4.0/.

\section{References}

1. K. Folkers, R.T. Major, J. Am. Chem. Soc. 59, 1580-1581 (1937)

2. A.F. Parsons, M.J. Palframan, Alkaloids 68, 39-81 (2010). https ://doi.org/10.1016/S1099-4831(10)06802-1

3. O. Flausino, L.D. Santos, H. Verli, A.M. Pereira, V.D. Bolzani, R.L. Nunes-de-Souza, J. Nat. Prod. 70, 48-53 (2007)

4. M. Ozawa, K. Honda, I. Nakai, A. Kishida, A. Ohsaki, Bioorg. Med. Chem. Lett. 18, 3992-3994 (2008)

5. S.A. Faggion, A.O.S. Cunha, H.A. Fachim, A.S. Gavin, W.F. dos Santos, A.M.S. Pereira, R.O. Beleboni, Epilepsy Behav. 20, 441-446 (2011)

6. F. Crestey, A.A. Jensen, M. Borch, J.T. Andreasen, J. Andersen, T. Balle, J.L. Kristensen, J. Med. Chem. 56, 9673-9682 (2013)

7. D.R. Callejon, T.B. Riul, L.G.P. Feitosa, T. Guaratini, D.B. Silva, A. Adhikari, R.L. Shrestha, L.M.M. Marques, M.D. Baruffi, J.L.C. Lopes, N.P. Lopes, Molecules 19, 5692-5703 (2014)

8. W.W. Cornelius, T. Akeng'a, G.O. Obiero, K.P. Lutta, Rec. Nat. Prod. 3, 96-103 (2009)

9. B.J. Zhang, M.F. Bao, C.X. Zeng, X.H. Zhong, L. Ni, Y. Zeng, X.H. Cai, Org. Lett. 16, 6400-6403 (2014) 
10. B.J. Zhang, W.N. Xiao, J. Chen, M.F. Bao, J. Schinnerl, Q. Wang, X.H. Cai, Tetrahedron (2019). https://doi.org/10.1016/j. tet.2019.130515

11. B.J. Zhang, B. Wu, M.F. Bao, L. Ni, X.H. Cai, RSC Adv. 6, 87863-87868 (2016)

12. J. Wu, B.J. Zhang, W.N. Xiao, M.F. Bao, X.H. Cai, RSC Adv. 7, 51245-51251 (2017)

13. J. Wu, B.J. Zhang, M.F. Bao, X.H. Cai, Nat. Prod. Res. 33, 2004 $2010(2019)$
14. H.E. Zhao, J. Wu, F.Q. Xu, M.F. Bao, C.S. Jin, X.H. Cai, Nat. Prod. Res. 33, 1298-1303 (2019)

15. K. Ito, H. Furukawa, H. Tanaka, J. Chem. Soc. Chem. Commun. 17, 1076-1077 (1970)

16. K. Ito, H. Furukawa, H. Tanaka, Yakugaku Zasshi 93, 1215-1217 (1973)

17. A.S. Chawla, S. Chunchatprasert, A.H. Jackson, Org. Magn. Reson. 21, 39-41 (1983)

18. Y. Tsuda, T. Sano, Alkaloids 48, 249-337 (1996). https://doi. org/10.1016/S1099-4831(08)60032-2 